\title{
ANALISIS PUTUSAN HAKIM TERHADAP TINDAK PIDANA MEMBERI KESEMPATAN PADA ORANG LAIN UNTUK MENGANGKUT MENJUAL BATU BARA
}

\author{
Shopi Yunandar ${ }^{1}$, Erlina B ${ }^{2}$, dan Baharudin ${ }^{3}$ \\ Program Studi Ilmu Hukum, Fakultas Hukum, Universitas Bandar Lampung \\ Jl. ZA Pagar Alam No 26, Labuhan Ratu, Kecamatan Labuhan Ratu, Kota \\ Bandar Lampung
}

Email : sopiyunandar090@gmail.com ${ }^{1}, \underline{\text { erlina@ubl.ac.id }}{ }^{2}, \underline{\text { baharudin@ubl.ac.id }}{ }^{3}$

Submisson : 6 Agustus 2021

Accepted : 10 september 2021

Publish : : 30 September 2021

\begin{abstract}
The company must have a Mining Business Permit, a Special Mining Business Permit (IUPK), and Business Permit to Transport and Sell Coal.One of the decisions regarding the criminal act of abusing mining business permits is in the decision Number:550/Pid.B/LH/2020/PN.Tjk.The problems in this study are what are the factors causing and how judges consider criminal acts to provide opportunities for other people to use Mining Business Permits (IUP),IUPK and Business Permits to transport and sell coal.Decision Study Number:550/Pid.B/LH /2020/PN.Tjk).This study using secondary data sources and primary data.Factors causing the crime to provide opportunities for other people to use IUP,IUPK, and Business Permits to transport and sell coal were carried out by the Defendant because the Defendant was a worker who was ordered by his superior named Limanto to submit documents on behalf of PT.Prisma Jaya to the truck driver for transport and deliver coal.The judge's consideration of criminal act provides an opportunity for other people to use the IUP,IUPK and business permits to transport and sell coal where the Judge gives a verdict that the defendant is subject to imprisonment for 10 months and the Defendant remains detained and
\end{abstract}


determines that the Defendant is burdened with paying court fees in amount of Rp.5,000.00.

Keywords: Judge's Decision, Crime, Transporting Selling Coal

\begin{abstract}
Abstrak
Perusahaan harus memiliki Izin Usaha Pertambangan, Izin Usaha Pertambangan Khusus (IUPK), dan Izin Usaha Untuk Mengangkut Menjual Batu Bara. Salah satu putusan terhadap tindak pidana penyalahgunaan izin usah pertambangan yakni dalam putusan Nomor :550/Pid.B/LH/2020/PN.Tjk. Permasalahan dalam penelitian ini yakni Apakah yang menjadi faktor penyebab dan bagaimana pertimbangan hakim terhadap tindak pidana memberikan kesempatan pada orang lain menggunakan Izin Usaha Pertambangan (IUP), IUPK dan Izin Usahanya untuk mengangkut menjual batu bara Studi Putusan Nomor :550/Pid.B/LH/2020/PN.Tjk). Pada penelitian ini menggunakan sumber data sekunder dan data primer. Faktor penyebab tindak pidana memberikan kesempatan pada orang lain menggunakan IUP, IUPK, dan Izin Usahanya untuk mengangkut menjual batu bara dilakukan oleh Terdakwa dikarenakan Terdakwa merupakan seorang pekerja yang diperintahkan oleh atasannya bernama Limanto untuk menyerahkan dokumen-dokumen atas nama PT Prisma Jaya kepada supir truk untuk mengangkut dan mengirimkan batu bara. Pertimbangan hakim terhadap tindak pidana memberikan kesempatan pada orang lain menggunakan IUP, IUPK dan Izin Usahanya untuk mengangkut menjual batu bara dimana Hakim memberikan putusan kepada terdakwa dikenakan pidana penjara selama 10 bulan dan Terdakwa tetap ditahan serta menetapkan agar Terdakwa dibebani membayar biaya perkara sejumlah Rp5,000.00.
\end{abstract}

Kata Kunci: Putusan, Tindak Pidana, Mengangkut Menjual Batu Bara

\title{
A. Pendahuluan
}

Keberadaan sumber daya alam yang berlimpah di suatu daerah bukan hanya dimaknai sebagai sumber pendapatan daerah saja namun juga mensyaratkan pengelolaan yang baik, berkelanjutan, dan memperhatikan aspek lingkungan 
hidup. Sinergi dan harmonisasi di antara seluruh pemangku kepentinganyang terlibat dalam pemanfaatannya, baik itu pemerintah, swasta, maupun masyarakat, menjadi kata kunci keberlanjutan produktivitas dan keseimbangan lingkungan, termasuk sumber daya tambang batubara.

Hukum pertambangan tidak pernah terlepas dari bagian lingkungan hidup merupakan anugerah Tuhan Yang Maha Esa yang wajib dilestarikan dan dikembangkan kemampuannya agar tetap dapat menjadi sumber penunjang hidup bagi manusia dan makhluk hidup lainnya demi kelangsungan dan peningkatan kualitas hidup itu sendiri, kejahatan lingkungan sering terjadi di sekeliling lingkungan kita, namun semua itu tanpa kita sadari.

Misalnya saja pada pertambangan, pertambangan merupakan usaha untuk menggali berbagai potensi-potensi yang terkandung dalam perut bumi.Negara menguasai secara penuh semua kekayaan yang terkandung di dalam bumi dan di pergunakan sebaik-baiknya untuk kemakmuran rakyat.Akan tetapi kenyataannya rakyat melakukan kegiatan penambangan dengan tidak memperhatikan aspekaspek yang penting di dalamnya, seperti tidak memperhatikan akibat yang ditimbulkan atau pengaruh dengan adanya pertambangan tersebut (pertambangan liar), namun tidak menutup kemungkinan pertambangan juga dilakukan oleh perusahaan tambang yang telah memiliki ijin resmi.Istilah hukum pertambangan merupakan terjemahan dan bahasa Inggris, yaitu Hukum pertambangan (mining law)adalah "hukum yang mengatur tentang penggalian atau pertambangan bijihbijih dan mineral-mineral dalam tanah". Definisi ini hanya difokuskan pada aktivitas penggalian atau pertambangan bijih-bijih.Penggalian atau pertambangan merupakan usaha untuk menggali berbagai potensi-potensi yang terkandung dalam perut bumi. Didalam definisi ini juga tidak terlihat bagaimana hubungan antara pemerintah dengan subyek hukum. Padahal untuk menggali bahan tambang itu diperlukan perusahaan atau badan hukum yang mengelolanya

Pengertian Pertambangan menurut Pasal 1 Ayat (1) Undang-undang No. 4 Tahun 2009 tentang Pertambangan Mineral dan Batubara, Pertambangan adalah sebagian atau seluruh tahapan kegiatan dalam rangka penelitian, pengelolaan dan pengusahaan mineral atau batubara yang meliputi penyelidikan umum, eksplorasi, 
studi kelayakan, konstruksi, penambangan, pengolahan dan pemurnian, pengangkutan dan penjualan, serta kegiatan pascatambang, Ayat (6) Usaha Pertambangan adalah kegiatan dalam rangka pengusahaan mineral atau batubara yang meliputi tahapan kegiatan penyelidikan umum, eksplorasi, studi kelayakan, konstruksi, penambangan, pengolahan dan pemurnian, pengangkutan dan penjualan, serta pascatambang, dan Ayat (19) Penambangan adalah bagian kegiatan usaha pertambangan untuk memproduksi mineral dan/atau batubara dan mineral ikutannya. ${ }^{1}$

Pada dasarnya pengaturan pengelolaan bahan galian atau bidang pertambangan di Indonesia, sama halnya dengan landasan hukum bidang lain pada umumnya, yaitu dimulai sejak pemerintahan Hindia Belanda. Sehingga, sampai dengan pemeritahan Orde Lama, secara konkret pengaturan pengelolaan bahan galian atau bidang pertambangan masih mempergunakan hukum produk Hindia Belanda yang langsung diadopsi menjadi hukum pertambangan Indonesia. Adapun pelaku pertambangan di Indonesia dapat dikategorikan menjadi tiga, yaitu Negara, Kontraktor dan Pemegang KP (Kuasa Pertambangan). ${ }^{2}$

Salah satu putusan terhadap tindak pidana penyalahgunaan izin usah pertambangan yakni dalam putusan Nomor :550/Pid.B/LH/2020/PN.Tjk. Dengan Terdakwa Agus Setiawan Als Gusti Bin Saiful terbukti secara sah dan meyakinkan bersalah melakukan tindak pidana "memberikan kesempatan dan sarana, untuk melakukan kejahatan, pengangkutan dan penjualan batubara yang bukan dari pemegang Izin Usaha Pertambangan (IUP), Izin Usaha Pertambangan Khusus (IUPK), atau Izin sebagaimana dalam dakwaan Alternatif Kedua Menjatuhkan pidana terhadap Terdakwa Agus Setiawan Als Gusti Bin Saiful Oleh karena itu dengan pidana penjara selama 10 (sepuluh) bulan dan denda sebesar Rp. 10.000.000,00 (sepuluh juta rupiah) dengan ketentuan apabila denda tersebut tidak dibayar maka diganti dengan penjara selama 2 (dua) bulan.

Berdasarkan uraian latar belakang diatas, permasalahan yang akan

\footnotetext{
${ }^{1}$ Pasal 1 Ayat (1), (6), dan (19) Undang-undang No. 4 Tahun 2009 tentang Pertambangan Mineral dan Batubara,

${ }^{2}$ http//PertambanganDinegaraIndonesia.com// Diakses Pada 20 September 2020 WIB
} 
diambil dalam penulisan artikel ini adalah :

a. Apakah yang menjadi faktor penyebab tindak pidana memberikan kesempatan pada orang lain menggunakan Izin Usaha Pertambangan (IUP), Izin Usaha Pertambangan Khusus (IUPK) dan Izin Usahanya untuk mengangkut menjual batu bara (Studi Putusan Nomor :550/Pid.B/LH/2020/PN.Tjk)?

b. Bagamana pertimbangan hakim terhadap tindak pidana memberikan kesempatan pada orang lain menggunakan Izin Usaha Pertambangan (IUP), Izin Usaha Pertambangan Khusus (IUPK) dan Izin Usahanya untuk mengangkut menjual batu bara (Studi Putusan Nomor :550/Pid.B/LH/2020/PN.Tjk)?

Penelitian ini menggunakan pendekatan penelitian yuridis empiris yakni penelitian hukum mengenai pemberlakuan atau implementasi ketentuan hukum normatif secara in action pada setiap peristiwa hukum tertentu yang terjadi dalam masyarakat. ${ }^{3}$ Dan penekitian ini juga menggunakan pendekatan yuridis normatif. Pendekatan yuridis normatif adalah pendekatan yang dilakukan berdasarkan bahan hukum utama, menelaah hal yang bersifat teoritis yang menyangkut asasasas hukum, konsepsi hukum, pandangan dan doktrin-doktrin hukum, peraturan dan sistem hukum dengan menggunakan data sekunder, diantaranya asas, kaidah, norma dan aturan hukum yang terdapat dalam peraturan perundang-undangan dan peraturan lainnya, dengan mempelajari buku-buku, peraturan perundang undangan dan dokumen lain yang berhubungan dengan penelitian yang akan dibahas. Pada penelitian ini menggunakan sumber data yakni bahan hukum primer, bahan hukum sekunder dan bahan hukum tersier.

\footnotetext{
${ }^{3}$ Abdulkadir Muhammad. 2004. Hukum dan Penelitian Hukum. Citra Aditya Bakti. Jakarta. hlm. 134.
} 
B. Hasil Penelitian dan Pembahasan

1. Faktor Penyebab Tindak Pidana Memberikan Kesempatan Pada Orang Lain Menggunakan Izin Usaha Pertambangan (IUP),Izin Usaha Pertambangan Khusus (IUPK) Dan Izin Usahanya Untuk Mengangkut Menjual Batu Bara (Studi Putusan Nomor
:550/Pid.B/LH/2020/PN.Tjk)

Dalam Putusan Nomor 550/Pid.B/LH/2020/PN.Tjk untuk membuktikan dakwaannya Penuntut Umum mengajukan saksi-saksi sebagai berikut.

1) Saksi Aji Lesmana Putra Bin Ujang Maming

Terdakwa membenarkan keterangan sasksi yang pada pokoknya menerangkan bahwa Saksi melakukan penangkapan terhadap para pengemudi pada hari Senin tanggal 6 Januari 2020 Pukul 23.00 Wib di jalan Tol LintasTran Sumatra KM. 33 Rest Area Desa Agom Kec. Kalianda Kabupaten Lampung Selatan yang bersama teman saksi. Bahwa yang melakukan pengangkutan batubara tersebut supir bernama Asrial Bin (Alm) Sarif dan Yul Hendri Lailatul .Q Bin Liswardi. Supir tersebut menggunakan mobil truk Hino berwarna hijau dengan nomor Polisi mobil Polisi BA 9998 AU dengan pengemudi atas nama Asrial Bin (Alm) Sarif. Dan mobil truk hino berwarna putih dengan nomor Polisi B 9394 TYT dengan pengemudi atas nama Yul Hendri Lailatul .Q Bin Liswardi.

Pengakuan dari para Pengemudi mobil tersebut bahwa pemilik batubara adalah Sdr. Maman yang beralamat di Bandung ( namun para supir tersebut tidak tahu alamat pastinya) dan batubara tersebut diangkut dari Wilayah Tanjung Enim Sumatera Selatan yang berasal dari Tambang Rakyat dan akan dibawa ke Kota Bandung Jawa Barat, namun alamat tujuannya tidak tahu . Bahwa para supir tersebut tidak memiliki Izin apapun saat melakukan pengangkutan batubara tersebut, yang dimiliki hanya surat jalan yang di keluarkan oleh PT. Prisma Jaya, namun surat jalan tersebut tidak sesuai dengan asal usul batubara tersebut dikarenakan batubara tersebut berasal dari Tambang Masyarakat di Tanjung Enim dan dalam surat berasal dari Lahat yang tidak memiliki Izin. 
2) Saksi Hendri Lailatul Q Bin Liswardi

Saksi menerangkan bahwa saat ini Saksi bekerja selaku supir mobil truck milik Sdr Yopi dan bekerja lebih kurang 18 (delapan belas) bulan dan bentuk usaha Sdr. Yopi tersebut merupakan Usaha Perorangan dan bergerak dibidang usaha jasa angkutan Pribadi. Saat dilakukan penangkapan mobil yang Saksi kemudikan tersebut sedang mengangkut batubara. Saksi ditangkap pada hari Senin tanggal 6 Januari 2020Pukul 23.00 Wib di jalan Tol Tran Sumatra KM. 33 Rest Area Desa Agom Kec. Kalianda Kabupaten Lampung Selatan oleh anggotaPolisi dari Polda Lampung.

Saksi menjelaskan bahwa pemilik batubara tersebut adalah Sdr. Maman yang beralamat di Bandung (namun Saksi tidak tahu alamatnya) dan batu bara tersebut diangkut dari Wilayah Tanjung Enim Sumatera Selatan dan akan dibawa ke Kota Bandung Jawa Barat, namun alamat tujuan Saksi tidak tahu, karena nantinya akan ada yang menjemput dan mengarahkan Saksi setelah sampai di Bandung. Awalnya Saksi mencari muatan melalui teman Saksi sesama supir, yang kemudian memberikan alamat pemiliknya bernama Maman, kemudian Saksi meneleponnya dan saat itu Saksi meminta muatan batubara, dan selanjutnya Sdr. Maman memberikan telepon Sdr. Ayu, kemudian Saksi meneleponnya dan Ayu memberikan muatan batubara milik Sdr. Maman tersebut melalui telepon.

Batubara yang Saksi angkut tersebut sebanyak 20 (dua puluh) Ton. Sesuai perjajian antara Saksi dengan Sdr. Maman, biaya angkut sebesar Rp.390.000 (tiga ratus sembilan puluh ribu rupiah) perton dan muatan Saksi sebanyak 20 (dua puluh) Ton, sehingga berjumlah sebesar Rp. 7.600.000 (tujuh juta enam ratus ribu rupiah). Cara Terdakwa Agus Setiawan Als Gusti memberikan surat jalan tersebut kepada saksi maupun Asrial Bin Sarif (alm) yakni ketika beristrahat di RM.Awa Juo sambil menunggu surat jalan, Terdakwa Agus Setiawan Als Gusti datang menemui kami dan menyerahkan surat jalan tersebut. 
Saksi melakukan muat batubara tersebut pada hari Jum'at tanggal 3 Januari 2020 sekira jam. 20.00 Wib yang berlokasi di Wilayah Kab. Tanjung Enim Sumatera Selatan. Saat melakukan muatan batubara tersebut bukan dilokasi Tambang dan tidak ada alat berat, sebab lokasi tersebut hanya dipinggir jalan aspal dan saat itu batubara tersebut berada didalam karung di satu lokasi tertutup seng, namun setelah diatas mobil Batubara tersebut dikeluarkan dari dalam karung. Sasksi tidak mengenali Sdr. Maman karena belum pernah bertemu dan komunikasi hanya melalui telepon. Saksi mengetahui jika batubara tersebut merupakan hasil usaha Pertambangan dan Saksi mengetahui jika melakukan pengangkutan hasil usaha pertambangan tersebut harus memiliki ijin Usaha pengangkutan batubara, namun hal tersebut Saksi lakukan dikarenaklan terpaksa sebap sulit mendapatkan muatan.

3) Saksi Sahrial Bin Syarif (Alm)

Saksi menjelaskan bahwa pada hari Senin tanggal 30 Desember 2019 saksi berangkat dari Padang membawa muatan semen dengan tujuan Rupit (Musi Rawas), setelah saksi selesai bongkar muatan semen tersebut pada hari Kamis tanggal 02 Januari 2020 saksi mencari muatan dan menghubungi sdr Maman (DPO), pada saat itu Sdr. Maman mengatakan ada muatan batu bara dari Tanjung Enim ke Bandung dengan kesepakatan biaya angkut sebesar Rp.390.000,- (tiga ratus Sembilan puluh ribu rupiah) perton, kemudian saksi menyetujuinya lalu sdr Maman memberikan nomor telepon sdr Ayu (DPO) orang yang akan memberikan muatan batu bara kepada saksi, lalu saksi berangkat menuju Tanjung Enim dengan menggunakan 1 (satu) unit mobil engkel merek Hino warna hijau dengan nomor Polisi BA-9998-AU milik CV Karya Mulya Abadi.

Pada hari Jumat tanggal 03 Januari 2020 saksi tiba di Tanjung Enim, lalu saksi langsung menghubungi Sdr Ayu, lalu saksi diminta untuk menunggu dirumah makan Awa Juo di Jalan Lintas Sumatera Desa Tanjung Lalang Kec. Tanjung Agung Kab. Muara Enim Provinsi Sumatera Selatan, sambil memberi alamat muat batu bara yang tidak jauh dari rumah makan tersebut . Hari Sabtu tanggal 04 Januari 2020 sekira pukul 24.00 Wib saksi diminta untuk kelokasi 
muat lalu saksi kelokasi muat batu bara, setibanya ditempat tersebut dipinggir jalan aspal dan saat itu batu bara berada didalam karung disatu lokasi tertutup seng lalu batu bara dimuat kedalam mobil saksi diangkut oleh buruh muat, setelah selesai muat saksi menutup muatan batu bara dengan menggunakan terpal, kemudian saksi kembali menuju Rumah Makan Awa Juo, pada saat dirumah makan Awa Juo Terdakwai Agus Setiawan Alias Gusti Bin Saiful memberikan surat jalan yang terbungkus didalam amplop serta dalam kondisi dilem kepada saksi dan mengatakan " ini surat jalan batu bara"

Setelah menerima surat jalan sekira pukul $14.30 \mathrm{Wib}$ saksi dan saksi Yul Hendri Lailatul Q Bin Liswardi berangkat menuju Bandung Jawa Barat. Kemudian pada hari Senin tanggal 06 Januari 2020 sekira pukul 23.00 Wib saksi dan saksi Yul Hendri Lailatul Q sedang berisitirahat di lokasi Rest Area Jalan Tol Lintas Sumatera Km 33 Desa Agom Kec. Kalianda Kabupaten Lampung Selatan, didatangi Tim Ditreskrimsus Polda Lampung diantaranya saksi Agung Pangestio Bin Aristio Prayudi dan Saksi Aji Lesmana Putra Bin Ujang Maming yang sebelumnya mendapatkan informasi dari masyarakat, ada mobil truck yang membawa muatan batu bara dari wilayah Tanjung Enim menuju Jakarta akan memasuki jalan tol Lintas Sumatera, kemudian Tim Ditreskrimsus Polda Lampung langsung melakukan pemeriksaan terhadap mobil turck yang terparkir dilokasi tersebut pada saat dilakukan pemeriksaan ditemukan muatan barang hasil tambang berupa batu bara didalam mobil yang saksi kendarai sebanyak 22 (dua puluh dua ton) dan didalam mobil yang dikendarai saksi Yul Hendri Lailatul Q sebanyak 20 (dua puluh ton).

Saat dilakukan pemeriksaan dokumen muatan mobil tersebut saksi memperlihatkan 1 (satu) lembar surat jalan No.00326751500/III/2019/P8 tanpa tanggal, 1 (satu) lembar surat tanda daftar perusahaan perseroaan terbatas an PT. Prisma Jaya Nomor:060614906176, tanggal 23 April 2012, 1 (satu) lembar surat izin usaha perdagangan (SIUP Kecil) an PT. PRISMA JAYA, Nomor : 511.3/siup/060/skr/2017, Tanggal 04 April 2017, 1 (satu) lembar surat keterangan Asal Barang (batu bara) No.762/SKABDPR/Pertamb/VI/2019 tanggal 05 Juni 2019 milik PT. PHL (Putra Hulu Lahat), 
Berdasarkan Dinas ESDM Prov Sumatera Selatan PT PRISMA JAYA tersebut tidak terdaftar sebagai pemegang IUP Pertambangan maupun Pengangkutan di Provinsi Sumatera Selatan, dan muatan mobil tersebut ternyata tidak memiliki dokumen kepemilikan batubara (asal usul) barang serta mobil yang dikendarai saksi tidak memiliki izin usaha Pertambangan Khusus (IUPK) pengangkutan.

4) Saksi Armaya Sentanu Pasek Bin (Alm) M. Imam Darta

Saksi menjelaskan bahwa saat ini saksi berdinas di Dinas Energi dan Sumber Daya Mineral Pemerintah Provinsi Sumatera Selatan sebagai Kepala Seksi Pembinaan Pengusahaan Bidang Pengusahaan Mineral dan Batubara. Berdasarkan data yang telah ahli perlihatkan dan diserahkan kepada Penyidik serta didukung dengan surat keterangan yang diterbitkan Dinas ESDM Provinsi Sumatera Selatan (surat terlampir), bahwa PT. Perisma Jaya tidak terdaftar sebagai pemegang Izin Usaha Pertambangan Khusus Pengangkutan Penjualan di Dinas ESDM Provinsi Sumatera Selatan.

5) Saksi David Junisa Bin Widodo

Saksi menjelaskan bahwa Saksi menjabat selaku staf bidang mineral dan batubara di Dinas ESDM Provinsi Lampung. Saksi menjelaskan yang dimaksud dengan penambangan adalah bagian kegiatan usaha pertambangan untuk memproduksi mineral dan/atau batubara dan mineral ikutannya sehingga yang dimaksud dengan usaha penambangan tanpa IUP adalah melakukan kegiatan usaha penambangan tanpa memiliki legalitas izin yang sah dari pejabat pemerintah yang berwenang sesuai ketentuan peraturan perundangundangan.

Bahwa apabila Badan Usaha, koperasi ataupun perseorangan yang melakukan kegiatan usaha pengangkutan dan atau jual beli batubara dengan tujuan untuk memperoleh keuntungan dan tanpa memiliki Izin Usaha Pertambangan (IUP) adalah tidak dapat dibenarkan menurut ketentuan Undang-Undang Republik Indonesia Nomor 4 Tahun 2009 tentang Pertambangan Mineral dan Batubara, karena adanya Pasal 36 dan Pasal 39 
Peratauran Pemerintah Nomor 23 Tahun 2010 tentang pelaksanaan kegiatan usaha pertambangan mineral dan batubara.

Berdasarkan hal tersebut Surat tanda registrasi kegiatan pengangkutan dan penjualan lintas provinsi dan/atau lintas negara Nomor 09481-00/TRAJ/DBB/2017 adalah terbitan Menteri tetapi sudah tidak berlaku lagi dan tidak dapat digunakan sebagai dasar kegiatan pengangkutan dan penjualan dan harus dilakukan penyesuaian menjadi IUP Operasi Produksi Khusus Pengangkutan dan Penjualan sesuai dengan ketentuan Pasal 111 point di Peraturan Menteri ESDM Nomor 11 Tahun 2018 tentang Tata Cara Pemberian Wilayah, Perizinan dan Pelaporan Pada Kegiatan Usaha Pertambangan Mineral dan Batubara. Atau surat tanda registrasi tersebut mungkin telah dilakukan penyesuaian menjadi IUP Operasi Produksi Khusus Pengangkutan dan Penjualan dan untuk memastikannya dapat berkoordinasi dengan Dirjen Minerba Kementerian ESDM.

Jika batubara yang diangkut terbukti berasal dari tambang yang tidak berijin (illegal mining) maka sesuai ketentuan pasal 161 Undang-Undang Nomor 4 Tahun 2009 dimana Setiap orang atau pemegang IUP Operasi Produksi atau IUPK Operasi Produksi yang menampung, memanfaatkan, melakukan pengolahan dan pemurnian, pengangkutan, penjualan mineral dan batubara yang bukan dari pemegang IUP, IUPK, atau izin sebagaimana dimaksud dalarn Pasal 37, Pasal 40 ayat (3), Pasal 43 ayat (2), Pasal 48, Pasal 67 aya t (1), Pasal 74 ayat (I), Pasal 81 ayat (2), Pasal 103 ayat (2), Pasal 104 ayat (3), atau Pasal 105 ayat (1) dipidana dengan pidana penjara paling lama 10 (sepuluh) tahun dan denda paling banyakRp 10.000.000.000,00 (sepuluh miliar rupiah),

Namun jika bataubara yang diangkut terbukti berasal dari tambang yang memiliki IUP Operasi Produksi Khusus/IPR/IUPK yang sah namun tidak memiliki IUP Operasi Produksi Khusus Pengangkutan dan Penjualan maka dapat diberikan sanksi administratif.

Berdasarkan hal tersebut bahwa Jaksa Penuntut Umum dalam Putusan Nomor 550/Pid.B/LH/2020/PN.Tjk mengajukan 5 orang saksi untuk membuktikan dakwaanya. Saksi-saksi yang dihadirkan terdiri dari 1 orang 
anggota kepolisan yang telibat langsung di dalam penangkapan Terdakwa, 2 orang saksi yang ikut terlibat dengan kegiatan Terdakwa dan 2 orang saksi ahli.

Berdasarkan hasil wawancara dengan Hakim dalam Putusan Nomor 550/Pid.B/LH/2020/PN.Tjk menjelaskana bahwa keterangan terdakwa yang memuat informasi tentang kejadian peristiwa pidana bersumber dari terdakwa, maka hakim dalam melakukan penilaian terhadap isi keterangan terdakwa haruslah cermat dan sadar bahwa ada kemungkinan terjadinya kebohongan atau keterangan palsu yang dibuat oleh terdakwa mengenai hal ikhwal kejadian atau peristiwa pidana yang terjadi. Keterangan Terdakwa juga hanya merupakan alat bukti terhadap dirinya sendiri.

Terdakwa Agus Setiawan als Gusti Bin Saiful di dalam persidangan menjelaskan keterangan sebagai berikut :

1) Terdakwa kenal dengan saksi yang dihadirkan oleh Jaksa Penuntu Umum yakni sasksi Asrial Bin Alm Sarif adalah Supir yang menerima surat jalan dari Terdakwa yang untuk dan atas nama PT. Prisma Jaya pada tanggal 3 Januari 2020 di Rumah Makan Awa Juo di Jln. Lintas Sumatera Desa tanjung Lalang Kec. Tanjung Agung kab. Muara Enim Provinsi Sumatera Selatan. Terdakwa juga kenal dengan saksi Yul Hendri Lailatul Q Bin Liswardi, adalah Supir yang menerima surat jalan dari Terdakwa yang untuk dan atas nama PT. Prisma Jaya pada tanggal 3 Januari 2020 di Rumah Makan Awa Juo di Jln. Lintas Sumatera Desa tanjung Lalang Kec. Tanjung Agung kab. Muara Enim Provinsi Sumatera Selatan.

2) Terdakwa adalah orang yang ditugaskan oleh laki-laki bernama Limanto, yang beralamat di Jln. Damai RT 3 RW 11 Kel. Tanjung Enim Selatan kab. Muara Enim Provinsi sumatera Selatan untuk mengantarkan surat kepada Supir-supir yang muat dan angkut batubara dari Tanjung Enim Kab. Muara Enim yang menggunakan Dokumen Surat atas nama PT. Prisma Jaya.

3) Bahwa Surat jalan, Surat Tanda Daftar Perusahaan Terbatas An. PT. Prisma Jaya, Surat Izin Usaha Perdagangan (SIUP Kecil) An. PT. Prisma Jaya.dan Surat Keterangan Asal Barang, Dokumen tersebut adalah benar dokumen yang Terdakwa serahkan kepada saksi Asrial Bin Alm Sarif dan Yul Hendri Lailatul 
Q Bin Liswardi pada tanggal 3 Januari 2020 di Rumah Makan Awa Juo, dokumen tersebut di atas adalah dokumen yang Terdakwa terima dari Sdr. Limanto, setahu Terdakwa dia selaku pengurus PT. Prisma Jaya dan Limanto mendapatkan surat tersebut dari Sitorus selaku pemilik surat.

4) Terdakwa mengenali kendaraan yang digunkan oleh saksi Asrial Bin Alm Sarif dan saksi Yul Hendri Lailatul Q Bin Liswardi.

5) Terdakwa tidak tahu dimuat dari lokasi Stock Pile siapa dan batubara yang ada di masing-masing bak kendaraan tersebut di atas adalah batubara dari hasil pertambangan rakyat, maksudnya adalah dari hasil pertambangan rakyat yang tidak memiliki izin yang ada disekitar Wilayah Tanjung Lalang, Tanjung Agung, Kab. Muara Enim Provinsi Sumatera Selatan dan Terdakwa mengetahuinya adalah karena memang di wilayah Kab. Muara Enim Provinsi Sumatera Selatan memang banyak lapak-lapak atau Stock Pile yang menampung batubara hasil pertambangan illegal yang dilakukan masyarakat sekitar yang umumnya dimuat kedalam karung dan saat dimuat kedalam Truck biasanya karung tersebut disobek atau istilahnya dicurah dan jika batubara tersebut adalah hasil pertambangan yang sah sudah pasti tidak menggunakan Dokumen Surat PT. Prisma Jaya untuk kelengkapan dalam perjalanan pengangkutan batubara tersebut (pasti menggunakan Dokumen izin miliknya sendiri) dan dan umumnya untuk Supir yang asal dari Luar Provinsi Sumatera Selatan menyebut Wilayah Tanjung Lalang atau Tanjung Agung adalah sama dengan Tanjung Enim.

6) Sepengetahuan Terdakwa adalah karena kegiatan muat dan pengangkutan batubara dari hasil pertambangan rakyat tersebut tidak ada memiliki dokumen sehingga menggunakan dokumen PT. Prisma Jaya agar seolah-olah batubara yang dimuat dan diangkut dari hasil pertambangan rakyat yang ada di Kab. Muara Enim tersebut adalah memiliki Surat atau Izin

Berdsasarkan uraian tersebut bahwa terhadap keterangan terdakwa sebagai alat bukti terdapat dalam Pasal 184 KUHAP. Alat bukti yang sah menurut Sistem Peradilan Pidana di Indonesia ialah sebagaimana yang ditentukan dalam Pasal 184 Ayat 1KUHAP yaitu keterangan saksi, keterangan ahli, surat, petunjuk dan 
keterangan Terdakwa. Keterangan Terdakawa sangat penting dalam pembuatan keputusan suatu perkara Pidana, karena apabila mengacu pada hukum acara pidana, pemeriksaan pembuktian tetap diperlukan sekalipun terdakwa mengakui tindak pidana yang didakwakan kepadanya. Apabila terdakwa mengakui kesalahan yang didakwakan kepadanya, penuntut umum dan persidangan tetap berkewajiban membuktikan kesalahan terdakwa dengan alat bukti yang lain.

Dalam Putusan Nomor 550/Pid.B/LH/2020/PN.Tjk Jaksa Penuntut Umum menghadirkan barang bukti berupa :

1) 1 (satu) Unit Kendaraan Truck Merek HINO jenis Lohan engkel, Warna Hijau, dengan nomor Polisi BA 9998 AU, Nomor rangka : MJEFG8JLL7JG10037, Nomor Mesin: J08EVGJ10162 berikut STNK dengan membawa + 22 (dua puluh dua) Ton Batubara.

2) 1 (satu) Unit Kendaraan Truck Merek HINO jenis Lohan engkel, dengan nomor Polisi B 9394 TYT rangka : MJEFG8JTKAJG17881, Nomor Mesin: J08EUGJ21683 Berikut STNK dengan membawa dan memuat +20 Ton Batubara.

3) 1(satu) Lembar SIM B-2 an. Asrial Bin (Alm) Sarif, 1 (satu) lembar SIM B-1 a.n. Yul Hendri Lailatul .Q Bin Liswardi.

4) 5 (Lima) lembar surat jalan pengiriman batu bara dengan transfortir an PT Prisma Jaya.

5) 2 (dua) Lembar Surat jalan No ; 00326751500/ III / 2019 / P8, tanpa tanggal.

6) 2 (dua) Lembar Surat Tanda Daftar Perusahaan Perseroaan Terbatas An. PT. Perisma Jaya Nomor : 060614906176, Tanggal 23 April 2012.

7) 2 (dua) Lembar Surat Izin Usaha Perdagangan (SIUP Kecil) An. PT. Perisma Jaya, Nomor : 511.3/SIUP/060/SKR/2017, Tanggal 4 April 2017.

8) 2 (dua) Lembar Surat Keterangan Asal Barang (Batubara) No : 762/SKABDPR/ Pertamb/VI/2019, Tanggal 5 Juni 2019 Milik PT. PHL (Putra Hulu Lahat),

9) 2 (dua) unit handphone. 
Kitab Undang-undang Hukum Acara Pidana memang tidak menyebutkan secara jelas tentang apa yang dimaksud dengan barang bukti. Namun dalam Pasal 39 ayat 1 KUHAP yang dapat dikenakan penyitaan adalah :

1. Benda atau tagihan tersangka atau terdakwa yang seluruh atau sebagian diduga diperoleh dari tindakan pidana atau sebagai hasil dari tindak pidana;

2. Benda yang telah dipergunakan secara langsung untuk melakukan tindak pidana atau untuk mempersiapkannya;

3. Benda yang dipergunakan untuk menghalang-halangi penyidikan tindak pidana;

4. Benda yang khusus dibuat atau diperuntukkan melakukan tindak pidana;

5. Benda lain yang mempunyai hubungan lansung dengan tindak pidana yang dilakukan.

Benda yang berada dalam sitaan dapat digunakan untuk kepentingan penyidikan, penuntutan dan mengadili perkara pidana, sepanjang memenuhi ketentuan Pasal 39 ayat 1 KUHAP. Barang bukti yang digunakan oleh terdakwa untuk melakukan suatu delik atau sebagai hasil suatu delik, disita oleh penyidik untuk digunakan sebagai barang bukti pengadilan. Dalam Pasal 181 KUHAP majelis hakim wajib memperlihatkan kepada terdakwa segala barang bukti dan menanyakan kepadanya apakah ia mengenali barang bukti terebut. Jika dianggap perlu, hakim sidang memperlihatkan barang bukti tersebut.

Dari uraian di atas dapat disimpulkan bahwa yang disebut dengan barang bukti adalah :

a. Barang yang dipergunakan untuk melakukan tindak pidana

b. Barang yang dipergunakan untuk membantu melakukan suatu tindak pidana

c. Benda yang menjadi tujuan dari dilakukannya suatu tindak pidana

d. Benda yang dihasilkan dari suatu tindak pidana

e. Benda tersebut dapat memberikan suatu keterangan bagi penyelidikan tindak pidana tersebut, baik berupa gambar ataupun berupa rekaman suara

f. Barang bukti yang merupakan penunjang alat bukti mempunyai kedudukan yang sangat penting dalam suatu perkara pidana. Tetapi kehadiran suatu barang bukti tidak mutlak dalam suatu perkara pidana, karena ada beberapa tindak 
pidana yang dalam proses pembuktiannya tidak memerlukan barang bukti, Sehingga barang bukti memiliki fungsi di dalam sidang di pengadilan yakni menguatkan kedudukan alat bukti yang sah, mencari dan menemukan kebenaran materiil atas perkara sidang yang ditangani. Setelah barang bukti menjadi penunjang alat bukti yang sah maka barang bukti tersebut dapat menguatkan keyakinan hakim atas kesalahan yang didakwakan Jaksa Penuntut Umum.

Fakta hukum adalah fakta atau keadaan yang tidak dibantah atau yang bersesuaian satu sama lain berdasarkan keterangan saksi dan keterangan terdakwa serta barang bukti yang relevan dengan unsur dakwaan. Berdasarkan alat bukti dan barang bukti yang diajukan dalam Putusan Nomor 550/Pid.B/LH/2020/PN.Tjk diperoleh fakta-fakta hukum sebagai berikut:

1) Bahwa benar Terdakwa kenal dengan Asrial Bin Alm Sarif tersebut adalah Supir yang menerima surat jalan dari Terdakwa yang untuk dan atas nama PT. Prisma Jaya pada tanggal 3 Januari 2020 di Rumah Makan Awa juo di Jln. Lintas Sumatera Desa tanjung Lalang Kec. Tanjung Agung kab. Muara Enim Provinsi Sumatera Selatan.

2) Bahwa benar Terdakwa juga kenal dengan saksi Yul Hendri Lailatul Q Bin Liswardi, adalah Supir yang menerima surat jalan dari Terdakwa yang untuk dan atas nama PT. Prisma Jaya pada tanggal 3 Januari 2020 di Rumah Makan Awa Juo di Jln. Lintas Sumatera Desa tanjung Lalang Kec. Tanjung Agung kab. Muara Enim Provinsi Sumatera Selatan.

3) Bahwa benar Terdakwa adalah orang yang ditugaskan oleh Limanto, yang beralamat di Jln. Damai RT 3 RW 11 Kel. Tanjung Enim Selatan kab. Muara Enim Provinsi Sumatera Selatan (Hp_0813-8088-1120) untuk mengantarkan surat kepada supir-supir yang muat dan angkut batubara dari Tanjung Enim Kab. Muara Enim yang menggunakan Dokumen Surat atas nama PT. Prisma Jaya.

4) Bahwa benar Surat jalan, Surat Tanda Daftar Perusahaan Terbatas An. PT. Prisma Jaya, Surat Izin Usaha Perdagangan (SIUP Kecil) An. PT. Prisma Jaya.dan Surat Keterangan Asal Barang, dokumen tersebut adalah benar 
dokumen yang Terdakwa serahkan kepada Asrial Bin Alm Sarif selaku Suppir Truck Hino Lohan warna Hijau dengan Nopol BA 9998 AU dan Yul Hendri Lailatul Q Bin Liswardi selaku Supir Truck Hino Lohan warna Putih dengan Nopol B 9394 TYT yang bermuatan batubara sekitar 20 Ton pada tanggal 3 Januari 2020 di Rumah Makan Awa Juo, dan dokumen tersebut adalah dokumen yang Terdakwa terima dari Sdr. Limanto, setahu Terdakwa dia selaku pengurus PT.Prisma dan Limanto mendapatkan surat tersebut dari Sitorus selaku pemilik surat.

5) Bahwa benar Terdakwa mengenali untuk kendaraan No.Pol B 9394 TYT Supir An. Yulhendri Bin Liswardi dan kendaraan No.Pol BA 9998 AU Supir An. Asrial Bin Syarif, Terdakwa tidak tahu dimuat dari lokasi Stock Pile Siapa dan batubara yang ada di masing-masing bak kendaraan tersebut di atas adalah batubara dari hasil pertambangan rakyat, maksudnya adalah dari hasil pertambangan rakyat yang tidakmemiliki izin yang ada disekitar Wilayah Tanjung Lalang, Tanjung Agung, Kab. Muara Enim Provinsi Sumatera Selatan dan Terdakwa mengetahuinya adalah karena memang di wilayah Kab. Muara Enim Provinsi Sumatera Selatan memang banyak lapak-lapak atau Stock Pile yang menampung batubara hasil pertambangan illegal yang dilakukan masyarakat sekitar yang umumnya dimuat kedalam karung dan saat dimuat kedalam Truck biasanya karung tersebut disobek atau istilahnya dicurah dan jika batubara tersebut adalah hasil pertambangan yang Sah sudah pasti tidak menggunakan dokumen Surat PT. Prisma Jaya untuk kelengkapan dalam perjalanan pengangkutan batubara tersebut dan umumnya untuk Supir yang asal dari Luar Provinsi Sumatera Selatan menyebut Wilayah Tanjung Lalang atau Tanjung Agung adalah sama dengan Tanjung Enim

6) Bahwa benar sepengetahuan Terdakwa adalah karena kegiatan muat dan pengangkutan batubara dari hasil pertambangan rakyat tersebut tidak ada memiliki dokumen sehingga menggunakan Dokumen PT. Prisma Jaya agar seolah-olah batubara yang dimuat dan diangkut dari hasil pertambangan rakyat yang ada di Kab. Muara Enim tersebut adalah memiliki Surat atau Izin.; 
Berdasarkan uraian tersebut diatas bahwa fakta hukum yang didapatkan di dalam Putusan Nomor 550/Pid.B/LH/2020/PN.Tjk yakni fakta atau keadaan yang tidak dibantah atau yang bersesuaian satu sama lain berdasarkan keterangan saksi dan keterangan terdakwa serta barang bukti yang relevan dengan unsur dakwaan.

Berdasarkan hasil wawancara dengan Hakim bahwa Terdakwa telah didakwa oleh Penuntut Umum dengan dakwaan yang berbentuk alternatif, sehingga Majelis Hakim dengan memperhatikan fakta-fakta hukum tersebut diatas memilih langsung dakwaan Alternatif Kedua sebagaimana diatur dalam Pasal 161 Undang-Undang Republik Indonesia Nomor 4 tahun 2009 tentang Pertambangan Mineral Dan Batu Bara Jo Pasal 56 ke-2 KUHP.

Dalam Pasal 161 Undang-Undang Nomor 4 tahun 2009 tentang Pertambangan Mineral Dan Batu Bara yang berbunyi :

"Setiap orang atau pemegang IUP Operasi Produksi atau IUPK Operasi Produksi yang menampung, memanfaatkan, melakukan pengolahan dan pemurnian, pengangkutan, penjualan mineral dan batubara yang bukan dari pemegang IUP, IUPK, atau izin sebagaimana dimaksud dalam Pasal 37, Pasal 40 ayat (3), Pasal 43 ayat (2), Pasal 48, Pasal 67 ayat (1), Pasal 74 ayat (1), Pasal 81 ayat (2), Pasal 103 ayat (2), Pasal 104 ayat (3), atau Pasal 105 ayat (1) dipidana dengan pidana penjara paling lama 10 (sepuluh) tahun dan denda paling banyak Rp10.000.000.000,00 (sepuluh miliar rupiah).”

Dalam Pasal 56 KUHAP Dipidana sebagai pembantu kejahatan yakni :

1. Mereka yang sengaja memberi bantuan pada waktu kejahatan dilakukan;

2. Mereka yang sengaja memberi kesempatan, sarana atau ke- terangan untuk melakukan kejahatan.

Unsur-unsur Dalam Pasal 161 Undang-Undang Nomor 4 tahun 2009 tentang Pertambangan Mineral Dan Batu Bara yakni :

\section{Setiap Orang}

Bahwa yang dimaksud setiap orang adalah siapa saja yang menjadi subyek hukum sebagai pendukung hak dan kewajiban, dimana perbuatan tersebut dapat dipertanggungjawabkan secara hukum. Kedepan persidangan telah diajukan Terdakwa yang telah mengaku sehat jasmani dan rohani bernama 
Agus Setiawan Als Gusti Bin Saiful dimana didepan persidangan Terdakwa membenarkan identitas dirinya sebagaimana tertera dalam surat dakwaan, di dalam persidangan Terdakwa mampu menjawab seluruh pertanyaan Majelis Hakim, Jaksa Penuntut Umum dengan baik dan lancar, dapat mengingat serta menerangkan yang benar sesuai dengan perbuatan Terdakwa telah dilakukan, hal tersebut menunjukan bahwa perbuatan Terdakwa telah maupun saat memberikan keterangan dimuka persidangan adalah berada dalam kondisi sehat jasmani dan rohani serta tidak ditemukan adanya alasan pembenar dan atau alasan pemaaf sehingga kepada Terdakwa dipandang mampu bertanggungjawab atas seluruh perbuatan pidana yang telah dilakukannya. Berdasarkan pertimbangan tersebut diatas Majelis Hakim berkesimpulan unsur ini telah terpenuhi.

2. Unsur Dengan Sengaja Memberikan Kesempatan, Sarana, Atau Keterangan Untuk Melakukan Kejahatan Menampung, Memanfaatkan, Melakukan Pengolahan Dan Pemurnian, Pengangkutan, Penjualan Mineral Dan Batu Bara Yang Bukan Dari Pemegang IUP, IUPK, Atau Izin.

Terdakwa adalah orang yang ditugaskan oleh Limanto, yang beralamat di Jln. Damai RT 3 RW 11 Kel. Tanjung Enim Selatan kab. Muara Enim Provinsi Sumatera Selatan untuk mengantarkan surat kepada Supir-supir yang memuat dan mengangkut batubara dari Tanjung Enim Kab. Muara Enim yang menggunakan Dokumen Surat atas nama PT. Perisma Jaya. Bahwa Surat jalan, Surat Tanda Daftar Perusahaan Terbatas An. PT. Perisma Jaya, Surat Izin Usaha Perdagangan (SIUP Kecil) An. PT. Perisma Jaya.dan Surat Keterangan Asal Barang. Dokumen tersebut diatas adalah benar dokumen yang Terdakwa serahkan kepada saksi Asrial Bin Alm Sarif dan Yul Hendri Lailatul Q Bin dan dokumen tersebut adalah dokumen yang Terdakwa terima dari Sdr. Limanto, setahu Terdakwa dia selaku pengurus PT.Perisma Jaya dan Limanto mendapatkan surat tersebut dari Sitorus selaku pemilik surat. Terdakwa telah memberikan kesempatan dan sarana kepada saksi Asrial dan saksi Yul Hendri dengan cara memberikan surat kelengkapan dokumen atas perintah Limanto 
dalam pengangkutan batubara yang bukan dari pemegang IUP, IUPK atau Izin, agar seolah olah batubara yang diangkut dari hasil pertambangan resmi ; Menimbang, bahwa berdasarkan pertimbangan tersebut diatas Majelis Hakim berkesimpulan unsur ini telah terpenuhi.

Bahwa oleh karena semua unsur dari Pasal 161 Undang-undang Republik Indonesia Nomor 4 tahun 2009 tentang Pertambangan Mineral dan Batubara Jo Pasal 56 ke-2 KUHP telah terpenuhi, maka Terdakwa haruslah dinyatakan telah terbukti secara sah dan meyakinkan bersalah melakukan tindak pidana sebagaimana didakwakan dalam dakwaan Alternatif Kedua. Menimbang, bahwa dalam perkara ini terhadap Terdakwa telah dikenakan penangkapan dan penahanan yang sah, maka masa penangkapan dan penahanan tersebut harus dikurangkan seluruhnya dari pidana yang dijatuhkan. Menimbang, bahwa oleh karena Terdakwa ditahan dan penahanan terhadap Terdakwa dilandasi alasan yang cukup, maka perlu ditetapkan agar Terdakwa tetap berada dalam tahanan.

Bahwa untuk menjatuhkan pidana terhadap Terdakwa, maka perlu dipertimbangkan terlebih dahulu keadaan yang memberatkan dan yang meringankan Terdakwa. Keadaan yang memberatkan yakni Perbuatan terdakwa meresahkan masyarakat. Sedangkan keadaan yang meringankan bahwa Terdakwa mengakui dan terus terang atas perbuatannya, Terdakwa bersikap sopan dipersidangan, Terdakwa menyesali perbuatannya dan berjanji tidak akan mengulanginya.

Bahwa oleh karena Terdakwa dijatuhi pidana maka haruslah dibebani pula untuk membayar biaya perkara. Memperhatikan, Pasal 161 Undang-undang Republik Indonesia Nomor 4 tahun 2009 tentang Pertambangan Mineral dan Batubara Jo Pasal 56 ke-2 KUHP dan Undang-undang Nomor 8 Tahun 1981 tentang Hukum Acara Pidana serta peraturan perundang-undangan lain yang bersangkutan maka Majalelis Hakim Mengadili :

1. Menyatakan Terdakwa Agus Setiawan Als Gusti Bin Saiful terbukti secara sah dan meyakinkan bersalah melakukan tindak pidana "memberikan kesempatan dan sarana, untuk melakukan kejahatan, pengangkutan dan penjualan batubara 
yang bukan dari pemegang IUP, IUPK, atau Izin sebagaimana dalam dakwaan Alternatif Kedua .

2. Menjatuhkan pidana terhadap Terdakwa Agus Setiawan Als Gusti Bin Saiful oleh karena itu dengan pidana penjara selama 10 (sepuluh) bulan dan denda sebesar Rp10,000,000.00 (sepuluh juta rupiah) dengan ketentuan apabila denda tersebut tidak dibayar maka diganti dengan penjara selama 2 (dua) bulan .

3. Menetapkan masa penangkapan dan penahanan yang telah dijalani Terdakwa dikurangkan seluruhnya dari pidana yang dijatuhkan.

4. Menetapkan agar Terdakwa tetap ditahan.

5. Menetapkan barang bukti

6. Menetapkan agar Terdakwa dibebani membayar biaya perkara sejumlah Rp5,000.00 (lima ribu rupiah)

Berdasarkan uraian tersebut bahwa Majalis Hakim dalam Putusan Nomor 550/Pid.B/LH/2020/PN.Tjk memberikan putusan pengadilan dengan dakwaan dimana Terdakwa Agus Setiawan Als Gusti Bin Saiful terbukti secara sah dan meyakinkan bersalah melakukan tindak pidana "memberikan kesempatan dan sarana, untuk melakukan kejahatan, pengangkutan dan penjualan batubara yang bukan dari pemegang IUP, IUPK, atau Izin. Terdakwa dikenakan pidana penjara selama 10 bulan dan Terdakwa tetap ditahan serta menetapkan agar Terdakwa dibebani membayar biaya perkara sejumlah Rp5,000.00 (lima ribu rupiah).

\section{Penutup}

Faktor penyebab tindak pidana memberikan kesempatan pada orang lain menggunakan Izin Usaha Pertambangan (IUP),Izin Usaha Pertambangan Khusus (IUPK) Dan Izin Usahanya untuk mengangkut menjual batu bara dilakukan oleh Terdakwa dikarenakan Terdakwa merupakan seorang pekerja yang diperintahkan oleh atasannya bernama Limanto untuk menyerahkan dokumen-dokumen atas nama PT Prisma Jaya kepada supir truk untuk mengangkut dan mengirimkan batu 
bara. Batu bara yang dimuat tersebut merupakan batu bara hasil pertambangan rakyat yang tidak memiliki izin atau pertambangan ilegal.

Pertimbangan hakim terhadap tindak pidana memberikan kesempatan pada orang lain menggunakan Izin Usaha Pertambangan (IUP), Izin Usaha Pertambangan Khusus (IUPK)dan Izin Usahanya untuk mengangkut menjual batu bara dimana Hakim memberikan putusan pengadilan dengan pertimbangan keterangan saksi, keterangan terdakwa, barang bukti yang dihadirkan, fakta hukum di dalam persidangan dan dengan dakwaan dimana Terdakwa Agus Setiawan Als Gusti Bin Saiful terbukti secara sah dan meyakinkan bersalah melakukan tindak pidana "memberikan kesempatan dan sarana, untuk melakukan kejahatan, pengangkutan dan penjualan batubara yang bukan dari pemegang IUP, IUPK, atau Izin. Terdakwa dikenakan pidana penjara selama 10 bulan dan Terdakwa tetap ditahan serta menetapkan agar Terdakwa dibebani membayar biaya perkara sejumlah Rp5,000.00 (lima ribu rupiah).

\section{Daftar Pustaka}

Abdulkadir Muhammad. 2004. Hukum dan Penelitian Hukum. Citra Aditya Bakti. Jakarta. hlm. 134

Alam, Sumarni. Tinjauan Yuridis Atas Tindak Pidana Korupsi Dalam Praktek di Indonesia. Jurnal Hukum Replik 5. No 2 (2017): 157-171.

BPKP, Strategi Pemberantasan Korupsi Nasional, (Jakarta: Pusat Pendidikan dan Pengawasan BPKP, Cet I, 1999) hlm 257-258

Hamzah Andi. Pemberantasan Korupsi melalui Hukum Pidana Nasional dan Internasional, (Jakarta, Raja Grafindo Persada, 2005) Hlm. 13-23

http//PertambanganDinegaraIndonesia.com// Diakses Pada 20 September 2020 WIB 
Pasal 1 Ayat (1) , (6), dan (19) Undang-undang No. 4 Tahun 2009 tentang Pertambangan Mineral dan Batubara, 